\title{
Elämänkaari ja kasvatus
}

En ole tietänyt nykyaikaisesta elämänkaaritutkimuksesta juuri mităăn ennenkuin luin $\mathrm{Ai}$ kuiskasvatuksen viime numeron. Tämă kyhăelmăni on kommentteja siihen.

Elämänkaari-käsite perustuu năhtăvăsti biologiseen eli materialistis-ateistiseen ihmisnäkemykseen. Tălloin jăă huomaamatta, ettă biologisen ihmisen lisăksi on myös toisenlainen ihminen. Uusi testamentti käyttăă edellisestă nimitystă ulkonainen ihminen ja jălkimmäisestă sisăllinen ihminen. Paavali sanoo: "Sentähden emme lannistu; vaan vaikka ulkonainen ihmisemme menehtyykin, niin sisällinen kuitenkin păivă păivăltă uudistuu"' (2 Kor. 4:16). Siis sisăllisen ihmisen kehitys ei ole kaaren, vaan se voi olla nousevan käyrän muotoinen. Biologiset lait mäăaăvăt kaaren muodon, kun taas sisăllisen ihmisen kehitys ei ole minkäăn lain mäărăämă. Tămă kehitys on paljolti riippumaton iăstä.

Tămă năkyy esim. lăäkäri Herbert Plüggen kuolemansairaiden toivon tutkimuksesta. Toivo on tărkeă eksistentiaali, ja sen kriisi, epätoivo, on kriiseistă pahin; se saattaa viedă kuolemaan biologisesti ja sosiaalisesti terveimmänkin. Plügge osoittaa, kuinka kuolemansairaudestaan tietoisella ihmisellä saattaa olla konkreettisiin asioihin kohdistuvia toiveita, esim. paranemisen toivo. Kun ne osoittautuvat mahdottomiksi sijaan voi tulla epămäăräinen "fundamentaalinen toivo". Se ei kohdistu sellaiseen minkă ihminen voi omistaa (haben), vaan siihen, mikä ihminen on (ist). Plügge karakterisoi tămän "itsensătodellistamiseksi tulevaisuudessa" tai "persoonan terveenä-olemiseksi (Heil-sein der Person)'”. Terveenä-oleminen ei tăllöin tietenkäăn ole medisiininen käsite. Vasta kun ihminen irroittautuu, puhdistuu mahdottomista, văäristă toiveista ja oivaltaa olevansa 'toivottomasti' kuoleman kynnyksellä, hän vapautuu henkisesti sairauden vankeudesta.

Ihminen voi siis iăstään riippumatta kasvaa ratkaisevalla tavalla vielă kuolinvuoteellaan. Hän voi antaa kuolemalleen sellaisen luonteen, ettă se vaikuttaa ylevơittäen ja lohduttaen hänen lähimmäisiinsă.

\section{Kriisit}

Kreikan sana krisis tarkoittaa erottamista, seulomista, valintaa, ratkaisua, tuomiota, riitaa (siită tulee sana kritiikki). Sillä on yhteys sanskriitin sanaan, joka merkitsee puhdistamista.

Otto Bollnow tarkastelee kriisiă eksistenssifilosofian valossa. Elämässä on jatkuvuutta (Stetigkeit), mutta myős jatkumattomuutta (Unstetigkeit). Jälkimmäisessä on kriisien sija.

Eksistenssifilosofian mukaan kriisit kuuluvat ihmisenă olemiseen, mikăli se on itsenă olemista, aitoa, varsinaista olemista (das eigentliche Sein). Ilman kriisejă ihminen madaltuu epävarsinaiseen olemiseen (das uneigentliche Sein). Kierkegaard sanoo, ettă ihminen on sită suurempi, mitä kovempien kriisien kautta hăn on kulkenut ja ettă kypsyys ei ole lainkaan saavutettavissa ilman kriisejă, tasaisen jatkuvuuden tuloksena.

On monenlaisia kriisejă, esim. moraalisia. Kaikkein väkevimpină ne koetaan uskonnollisessa elämässä. Uskonnollisessa kielessä keskeiset sanat kääntymys ja herätys tarkoittavat kriisiă. Kăăntymys on siină merkityksessă radikaalisin kriisi, ettă se saattaa muuttaa melkein koko elämăn: pukeutumisen, ruokailun, ammatin, ystäväpiirin jne.

Elämănkaaritutkimus tulee yksipuoliseksi, jos ihminen năhdäăn vain biologisena olentona (biologismi) tai jos elămănprosessi supistetaan (Yrjö-Paavo Hăyrysen tavoin?) vain yksilơn ja hănen sosiaalisen ympäristơnsă vuorovaikutukseksi (sosiologismi). Elämänjuoksussa on kysymys myös ihmisen suhteesta itseensă. Tăhän suhteeseen sisältyy usein uskonnollinen momentti.

Jukka Tuomisto ei ole tyytyvăinen elämänkaari-kăsitteeseen, mutta hănen mielestäăn siihen täytynee tyytyă; eihăn nimi asiaa pahenna. Eihän toki, mutta on olemassa myös sanan mahti: sanat voivat johtaa harhaan.

Se, mită on syntymăn ja kuoleman vălillä, ilmaistaan monissa kielissä liikettä ilmaisevalla sanalla: saks. Lebenslauf, engl. lifecourse, ransk. cours de la vie, ruots. levnadslopp, tansk. levnetsløp, eest. elukäik (verbi käiä = 
käydä), lat. cursus vitae, siis elämăn juoksu tai kulku. Kaari on geometrinen kuvio, engl. span. Onko elämänkaari-sana otettu perin harvinaisesta ilmaisusta lifespan? Ja minkä takia?

Kyllä aikuiskasvattajien pitäisi tarkkailla myős sanoja kriittisesti, ettei taas kävisi niin onnettomasti kuin ruvettaessa nimittămäăn aikuiskasvatusta aikuiskoulutukseksi. Sehän merkitsee poikkeamista kaikista muista kielistă ja tuottaa esim. kääntäjille vaikeuksia.

Miten aikuiskasvatuksessa pitäă suhtautua kriiseihin? Humanistisen aikuiskasvatuksen ylimpänă päămääränă on muuttaa epävarsinäisen oleminen varsinaiseksi. Kun siinä kriiseillă on tärkeă rooli, tuleeko kasvattajan yrittăă niită synnyttăă? Yleinen ohje lienee, ettei siihen pidä ryhtyă kriisien vaarallisuuden tähden. Pikemminkin on yritettävă auttaa kriisien voittamisessa, mikă saattaa tapahtua esim. siten, että koetetaan valaista kriisin luonnetta.

Mutta ehkä joskus pităă myős yrittăă ajaa ihminen kriisiin. Viittaan intellektuaalisen elämän kriisin kuuluisimpaan kuvaukseen, Platonin luolavertaukseen. Luolasta vapautunut koki valtavan järkytyksen oivaltaessaan, ettă se, mitä hän oli pitänyt totena ja todellisena, olikin vain varjokuvaa luolan seinămăllă. Hăn tunsi velvollisuudekseen palata luolaan kertoakseen sinne kahlehdituille totuuden. Nämä olivat valmiit surmaamaan totuudenpuhujan vălttyăkseen kriisiltä.

Platonilla oli vertausta kirjoittaessaan tietenkin mielessään Sokrates, joka ei arkaillut ajamasta kysymyksilläăn ihmisiă kriisiin.

\section{Vanhuuteen kasvattaminen}

Kasvatus vanhuuteen pitäă aloittaa nuoruudessa elinikäisen kasvatuksen periaatteen mukaisesti. Siksi elämänjuoksun loppupäă pităă tuntea. On sellaisia kasvatustehtäviä, joita ei voi enäă kunnolla suorittaa kun vanhuus on jo ovella tai astunut siită sisăän.

Tarkoitan harrastuksia. Niită on vaikea herättăă vanhuudessa ellei siementä ole kylvetty aikaisemmin. Minusta pelkkäă aikaa tappava vanhus on surkuteltava olento.

Aikuiskasvatukselle on annettu tehtäväksi "ohjata vapaa-ajan oikeaan käyttőon". On ohjattava ihmiset löytämäăn myös sellaisia vapaa-ajan harrastuksia, jotka tuovat sisältöa elämän viimeisiin vaiheisiin. Kaikki harrastukset eivät sellaisiksi ollenkaan sovi.

Tunnen vanhoja ihmisiä, joilla on jo varhain ollut jokin mieluinen harrastus. Työntäyteisină vuosikymmenină he ovat ehtineet sitä vain hieman vaalia silmälläpitäen sitä, että he eläkkeelle păăstyăăn antautuvat kokosydămisesti harrastukselleen. Näin siitä on tullut heille korvaamaton elämän rikkaus.

\section{Ylös alistuneisuudesta}

Pelkillă kasvatuksellisilla toimenpiteillă elämänkaarta ei käănnetä nousevaksi käyräksi. Tarvitaan myős yhteiskunnallisia toimenpiteită. Esim. pitäisi korjata se văäryys, ettă isovanhemmat on eristetty lapsenlapsistaan.

Kapitalistis-keynesiläis-kasvuideologinen yhteiskunta on ajautunut kriisiin (Gorz). Vihreiden ja muiden aatteiden pohjalta etsitäăn tietă pois kriiseistă.

Nyt olisi sopiva aika aikuiskasvattajien nousta sosiaalisesta resignaatiostaan. On sanouduttava irti yhteiskuntapolitiikan tavoitteita toteuttavasta palkkapiian virasta.

Aikuiskasvattajien pitäisi yhtenäisesti ryhtyä suunnittelemaan yhteiskunta sellaiseksi, että siinä ihmisten elămänjuoksu voisi mahdollisimman hyvin muodostua aikuiskasvatuksen ideaalien mukaiseksi. Jos politiikka demokratisoituu, kuten äskeisten eduskuntavaalien tulosten perusteella näyttää, poliitikot varmaankin ottaisivat siită jotakin onkeensa.

\section{Kirjallisuus}

Bollnow, O. 1959. Existenzphilosophie und Pădagogik. Kohlhammer, Stuttgart.

Gorz, A. 1982. Eläkő̋n tyőttơmyys. Kansan Sivistystyon Liitto. Helsinki.

Plügge, H. 1962. Wohlbefinden und Missbefinden. Tübingen. 